\title{
THE DETERMINANTS OF VOLUNTARY RISK DISCLOSURES: THE CASE OF SHARIAH COMPLIANT COMPANIES IN MALAYSIA
}

\author{
Nurul Fida Rosli*, Nor Farizal Mohammed, Zuraidah Mohd Sanusi ${ }^{1}$ \\ *Faculty of Accountancy Universiti Teknologi MARA, ${ }^{1}$ Accounting Research Institute, Universiti \\ Teknologi MARA
}

\begin{abstract}
Risk reporting is essential in notifying investors on how companies manage the risks they engage in. Even though companies nowadays release information through press releases, corporate websites, and other forms of communications, they still have to disclose more information in their annual reports. The objective of this study is to examine the determinants of voluntary risk disclosures of Shariah compliant companies (ShCCs) in Malaysia, focusing on the religiosity factor and the ownership structure. A quantitative analysis using secondary data was employed as a method to assess the annual reports of 116 Shariah compliant companies in Malaysia for the financial years of 2012 and 2013. The findings of this study reveal that the voluntary risk disclosures in ShCCs on average are not more than sixty per cent. This study indicates no relationship between the religiosity of board members and directors' ownership to the level of voluntary risk disclosure. More importantly, this study finds the relationship between the existence of government ownership and voluntary risk disclosure in ShCCs. The study adds value to the current body of knowledge in voluntary risk disclosures and suggests the importance of risk management information in the annual reports of ShCCs as Malaysia grows as a leading country in the Islamic economy.
\end{abstract}

Keywords: Voluntary Risk Disclosures; Corporate Governance; Shariah Compliant Companies; Risk Reporting; Malaysia

\section{INTRODUCTION}

The absence of risk management information in companies' annual reports have steered regulators as well as researchers (Ismail, 2013; Bursa Malaysia, 2012a; Cabedo \& Tirado, 2004) to demand for information on risks from these companies. The ever increasing corporate scandals have stunned the confidence among investors and creditors in companies' financial reporting (Ismail \& Rahman, 2013). Therefore, risk disclosure has become an important element in corporate communication (Beretta \& Bozzolan, 2004), where companies are encouraged to provide more voluntary information regarding their risk management (Securities Commission, 2012). Indeed, risk reporting and disclosures have become a main concern of many international accounting standard-setters and regulators (Atan et al., 2010). Companies that provide comprehensive reporting of their risk management will enhance their investor's confidence, as voluntary disclosure is viewed as credible information (Healy \& Palepu, 2001). In this case, voluntary disclosure may act as a mechanism to differentiate superior and significant information in

*Corresponding author's email: norfa783@salam.uitm.edu.my

(C) The Authors, published by EDP Sciences. This is an open access article distributed under the terms of the Creative Commons Attribution License 4.0 (http://creativecommons.org/licenses/by/4.0/). 
explaining mandatory information (Healy \& Palepu, 2001). Further, lack of comprehensive voluntary risk information will give impact on the business' future as well as investor's confidence (Cabedo \& Tirado, 2004; Ismail, Arshad, \& Othman, 2012). These disclosure practices regarding risks are expected more in Shariah Compliant Companies (ShCCs) as the principle of being transparent is in adherence to the Islamic value.

According to prior studies, a good governance practice enhances monitoring, thus provides an excellent economic communication, thereby enhancing voluntary disclosure in annual reports (Chen \& Janggi, 2000; Cheng \& Courtenay, 2006; Cheung, Connelly, Limpaphayom, \& Zhou, 2006; Eng \& Mak, 2003; Ho \& Wong, 2001). Corporate governance mechanism in terms of board of directors, holds the responsibility in realising the excellence of corporate governance practices, in which boards should establish clear roles and responsibilities in discharging its fiduciary and leadership functions (Securities Commission, 2012). Corporate governance mechanism as a monitoring tool ensures that financial statements prepared can deliver information that could help investors make decisions, for example, by disclosing important information on risks. A review of prior literature on corporate governance in Malaysia suggests that corporate governance factors such as directors' ownership, government ownership and ethnicity, are worthy to be investigated further in relation to the disclosure of financial statements.

Voluntary corporate disclosure has been comprehensively explored in recent years due to the growing importance of voluntary risk disclosures in the non-financial information of the annual reports (Ahmed H \& Mohd Ghazali, 2013; Amalina Wan Abdullah, Percy, \& Stewart, 2013; Ousama \& Fatima, 2010;). Nevertheless, the lack of studies on voluntary risk disclosure focusing on Shariah Compliant Companies in Malaysia is evident as most previous literatures focused more on Public Listed Companies and Islamic Financial Institutions (Ismail, 2013; Atan et al., 2010; R. F. Ismail et al., 2012; R. Ismail \& Rahman, 2011; Rahman, Kighir, Oyefeso, \& Salam, 2013). Hence, this study seeks to explore the impacts of social values of the companies' accomplishments, focusing on the determinants of voluntary risk disclosures in Shariah compliant companies. Therefore, the main objective of this study is to examine the determinants of voluntary risk disclosures of ShCCs in Malaysia. The sub-objectives of this study are; to examine the association of ethnicity of board with voluntary risk disclosure; to examine the association of boards' ownership with voluntary risk disclosure; and to examine the association of government ownership with voluntary risk disclosure. The following section provides the literature review and hypotheses development. Section 3 discusses the research design and methodology. Section 4 explains the findings, while section 5 concludes the study.

\section{LITERATURE REVIEW AND HYPOTHESES DEVELOPMENT}

The post 1997 Asian financial crisis has solved the liquidity problem resulting from surplus funds from the Islamic finance industries, which has led to the emergence of the Islamic Capital Market (ICM) (Bursa Malaysia, 2012b). The aim of setting up the ICM is to globalise Malaysia as a centre for ICM in the Islamic economy. The ICM represents an assertion of religious law in capital market transactions where the "market is free from prohibited activities and elements such as riba (usury), maisir (gambling) and gharar (ambiguity)" (Bursa Malaysia, 2012b). The pace of development in the Islamic capital market has created the formation of various international Islamic organisations

[Type here] 
to study and promote this alternative market and has brought up Malaysia as an international Islamic finance hub (Nazri et al., 2014). Today, the Islamic capital market runs parallel to the conventional capital market and provide investors an alternative investment philosophy that is rapidly gaining acceptance and entrance by Muslims and non-Muslims (Ousama \& Fatima, 2010b).

Malaysia has put on a continuous effort in promoting the country as a regional Islamic capital market. There are needs for continuous changes and improvements in meeting the complex and different demands of various sectors of the economy (Nazri et al., 2014). One of the efforts is the classification of companies as Shariah Compliant Companies (ShCCs), aiming to help investors who are concerned about the halal status of their investments to make their decisions. Shariah compliant companies are companies that are regulated and monitored by the Shariah Advisory Council (SAC). These companies refrain from being involved in activities such as gambling and alcoholic business matters in order to comply with the Islamic Shariah principles. They are also more likely to adhere to Islamic values such as accountability and transparency, as Islam requires a total commitment of Shariah in all aspects of life. Thus, in order to support the government's efforts, ShCCs must provide an excellent form of communication through their mandatory reports and voluntary reports of financial results regarding risks and other vital information. Consequently, this study hopes to contribute towards the understanding of risk management in the annual reports of ShCCs, hence assisting in strengthening the Islamic economy of this country. The Financial Accounting Standard Board describes "voluntary disclosures" as "information primarily outside of the financial statements that are not explicitly required by accounting rules or standards" (MASB, 2009). As such, voluntary disclosures involve disclosures in excess of the requirements and include accounting and other information that managers of a company deem relevant to the needs of various stakeholder groups (Jensen, 1993). Furthermore, risk disclosure is an example of voluntary disclosure and has become an essential part of corporate disclosure where it will enhance the transparency level of the company as well as the investor's confidence towards them (Linsley \& Shrives, 2005, 2006b). Similarly, Yazid and Muda (2006) found that companies with risk disclosure provided better assessments concerning the risks they faced. By disclosing the information, they are more likely to take the necessary actions to reduce their exposure to losses.

Organisational legitimacy is the congruence between the social values associated with or implied by their activities and the norms of acceptable behaviour in the larger social system in which they are a part of (Tilling, 2004). Voluntarily disclosing information is one way to reduce the legitimacy gap (R. M. Haniffa \& Cooke, 2005; Tilling, 2004). The legitimacy theory is defined as "a generalised perception or assumption that the actions of any entity are desirable, proper, or appropriate within some socially constructed system of norms, values, beliefs and definitions", (Suchman, 1995). There are four broad legitimation strategies identified by prior studies that firms may use to secure organisational legitimacy, which are: informing stakeholders about intended improvements in performance; seeking to change stakeholder's perceptions of an event; distracting attention away from an issue; and changing external expectations about its performance (Lindblom, C.K., 1994). As a result, this study is expected to assist the literature in exploring the behaviour of voluntary risk disclosure through these companies' responses to the organisational legitimacy gap. ShCCs are expected to provide more information on voluntary risks in order to respond to the society on their responsiveness towards the changing environments of the economy. 
This study investigates the variation of Muslim directors on board and examines whether directors' and government ownership in the companies affect their percentage of voluntary risk disclosure. Market to book ratio for each Shariah compliant company is used to control the effect of size differences. Figure 1.1 illustrates the framework of this research. This section provides the linkage between theoretical as well as empirical and research questions proposed in this study, from which the research hypotheses are then constructed

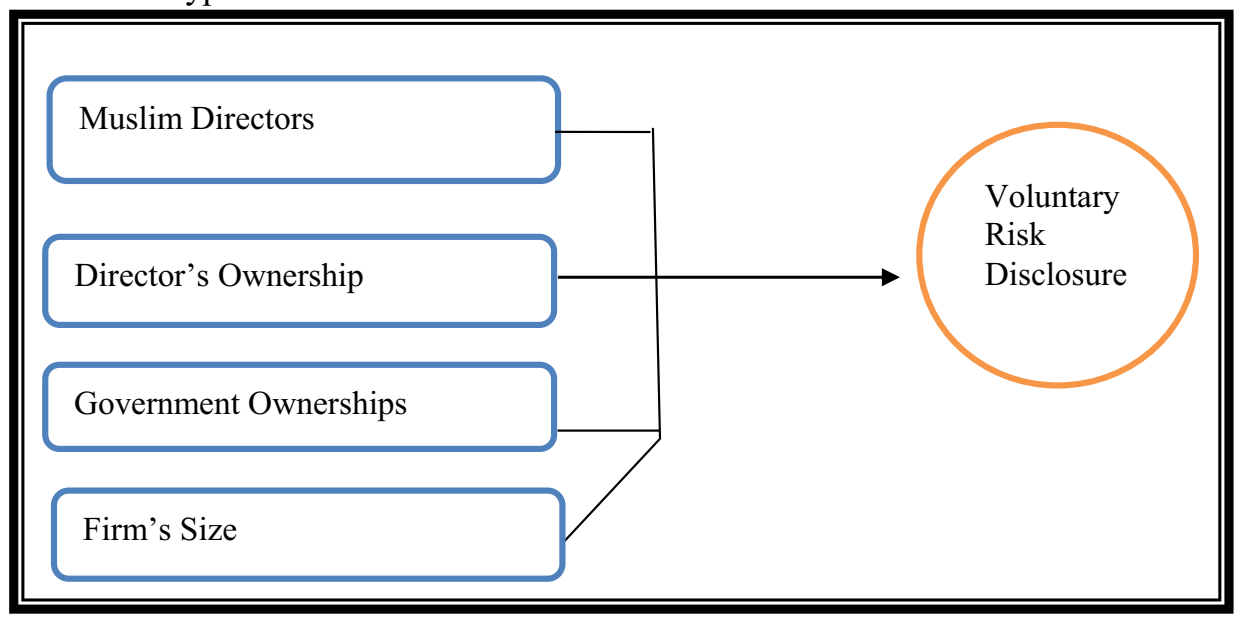

Figure 1.1: The framework of the research

The following hypotheses are built up based on the findings and arguments from prior studies. Shariah compliant companies are expected to be in line with Shariah rules and regulations set by the SAC. Thus, it is expected that these companies are operated by people who are knowledgeable about the Islamic values. However, in this multi-racial country, not all ShCCs are operated by Muslims. In the context of Malaysia, which is a multicultural country, it is very important to distinguish the attitudes and behaviours of the different races in society that influence the extent of voluntary disclosure (Haniffa \& Cooke, 2000). The presence of religiosity as proxy for culture of decision makers within an organisation is important in some countries because the traditions of a nation are instilled in its people and might help explain why things are as they are (R. M. Haniffa $\&$ Cooke, 2005). The existence of clearly identifiable ethnic domination gives rise to differential monitoring in a company (Yatim, Kent, \& Clarkson, 2006). Muslims are obliged to be transparent in showing their business matters, which is stated in the Holy Quran, Chapter Al- Baqarah, verse 282 ;

"O ye who believe! When ye deal with each other, in transactions involving future obligations in a fixed period of time, reduce them to writing. Let a scribe write down faithfully as between the parties...."

Corporations are responsible for a wide spectrum of stakeholders and their aims should not strictly be on monetary values, but also on social responsibilities to the Ummah. Corporations should disclose information regarding its policies, especially on the risks they are facing. Haniffa \& Cooke (2000) indicated cultural and corporate governance as determinants in voluntary disclosures. According to Yatim, Kent and Clarkson (2006), Bumiputera-dominated companies appear to have a better risk management system than non-Bumiputera dominated companies. Consequently, the presence of Islamic Malay directors is expected to give influence to the company's disclosure

[Type here] 
culture and practices due to their devotion to the Islamic values. In Malaysia, quite a number of public companies are family owned and managed, and it is more common among the Chinese (Ibrahim \& Abdul Samad, 2011; Marimuthu, 2010). When family members own and manage the companies, they are less likely to accept their obligations to society (Haniffa \& Cooke, 2000). They would prefer to have managers and directors from their own group, and this would limit the reporting practices to meet the bare minimum legal requirements. Thus, it may be expected that Chinese-managed companies would be less transparent or more secretive in their disclosure practices.

H1: Ceteris paribus, there is a positive relationship between voluntary risk disclosures and the existence of Muslim directors in boards of the company.

According to MCCG (2012), the board of directors is responsible in managing all risks involved in the business and ensuring an effective system to monitor and manage the risks. The responsibilities held by the board of directors include determining the company's level of risk tolerance and actively identify, assess and monitor key business risks to safeguard shareholders' investments and the company's assets, and ensure that their risk management system is viable and robust (Securities Commission, 2012). The board's duty is to serve the interest of shareholders as well as make the company known to the outside environment through disclosure (M. Akhtaruddin \& Haron, 2010). The rationale for the existence of director ownership is to make the directors have the perspectives of real owners of the company in which they are expected to provide a strategic leadership that aligns with the company's interest (Chatterjee, 2009). The decisions on disclosure are in the boards' hands (M. Akhtaruddin \& Haron, 2010), therefore, the existence of director ownership in the company will enable them to serve the shareholders better as strategic leaders and thus provide more information on voluntary disclosure. However, studies found managerial ownership to be negatively associated with the extent of voluntary disclosure in Malaysian and Singaporean listed companies (Eng \& Mak, 2003; Mohd Ghazali, 2007) and the results are significant. There are many reasons to explain this negative relationship. According to Darmadi (2013) and Ghazali (2007), voluntary disclosure is the director's decision and they will disclose them voluntarily when the benefits outweigh the associated costs. Similarly, Jiang et al. (2009) indicated that directors provide minimum disclosures and less credible disclosures to outsiders to control and exploit their private benefits. Additionally, a highly concentrated ownership in a company results in less disclosure, especially on risks, as they discuss it in board meetings and not via annual reports (Konishi \& Ali, 2007; Mokhtar \& Mellett, 2013). Due to inconsistent arguments and findings, it is expected that director ownership has a relationship with voluntary disclosures.

$\mathrm{H} 2$ : Ceteris paribus, there is a significant relationship between voluntary risk disclosures and director's ownership held in the company.

The government of Malaysia owns a significant portion of corporate ownership (Claessens, Djankov, \& Lang, 2000; Mohd Ghazali, 2010). The other ownership structure that gives a significant influence to voluntary disclosure is government ownership. In the sense of risk disclosure, government owned companies may disclose less in annual reports in order to avoid bad perceptions from the public, as they are strongly politically associated and may want to guard their 
political connections (Jiang, Habib, \& Hu, 2011; Mohd Ghazali, 2007). Conversely, Ghazali (2007) argued that government owned companies provide more voluntary disclosure because they are accountable to the public. This argument is supported by Mohd Ghazali and Weetman (2006), where companies that are held by the government are forced to provide more disclosure in their annual reports because the government is accountable to the public at large. Similarly, government owned companies' disclosure quality is higher than other companies because they are monitored by the government. Therefore, this study expects that ShCCs, in which the government owns a portion of their shares, will provide additional disclosure.

H3: Ceteris paribus, there is a positive relationship between voluntary risk disclosures and government ownership held in the company.

Previous studies found that the volume of voluntary disclosures are related to the size of the company (Ahmed Haji \& Mohd Ghazali, 2013; Haniffa \& Cooke, 2005; Ismail et al., 2012; Rahman et al., 2013). Normally, large companies tend to disclose more as they have a wider ownership base than smaller companies and they are more sensitive to political costs, giving them additional incentives for voluntary disclosures (Al-Janadi, Rahman, \& Omar, 2013). Therefore, the voluntary risk disclosure is related to the company's size.

$\mathrm{H} 4$ : There is a positive relationship between voluntary risk disclosures and the size of the company.

\section{RESEARCH DESIGN AND METHODOLOGY}

\section{Sample and Data Collection}

This study focuses on the disclosure made by Shariah Compliant Companies (ShCCs) that are listed in Bursa Malaysia which was obtained from it's website as well as from the Security Commission Malaysia's website. As of $31^{\text {st }}$ June 2014, there are a total of 666 ShCCs that are listed under Islamic securities in Bursa Malaysia. Only the top one hundred and fifty Shariah Compliant Companies are used as an initial sample based on capitalisation ranking on $31^{\text {st }}$ of December 2013. Companies with bigger market capitalisation are usually the top companies. The top companies are expected to disclose more information in their annual reports because they are more likely to be inspected by the regulators. However, financial industry companies such as banking, insurance, trust, closed-end funds and securities are excluded from the sample due to their nature of being governed by the additional regulation aside from Malaysian Financial Reporting Standards (Ismail \& Rahman, 2013).

The table below shows the sample selection process. From the initial sample of 150 companies, three of them are financial companies, seventeen are delisted companies from the 2012 listing, and fourteen of the companies' data are not available. After excluding these companies, the final sample consists of 116 companies.

\begin{tabular}{ll}
\hline & No. of Companies \\
\hline Initial sample & 150 \\
Less: companies in the finance industry & 3 \\
Less: delisted companies & 17
\end{tabular}

[Type here] 


\section{Table 3.1: Data sampling process}

The data used in this study were gathered from multiple sources of secondary data which were downloaded from the annual reports available on the Bursa Malaysia website. The information about the voluntary risk disclosure was extracted and collected from these annual reports, while the financial information of the companies, which were used as the control variable, were extracted from the Bloomberg database. Specifically, it was used to collect data on the control variable, which is size of the companies. All the collected data from the annual reports were hand collected. The annual reports for the period of 2012 to 2013 were collected, including the data of dependent and independent variables. Thus, this study observed the voluntary risk disclosures for the years of 2012 and 2013 because these two years were the latest and had complete annual reports of the selected sample company. Prior to these, total observations for this study were 232. This study incorporated both corporate governance and personal characteristics of directors into the voluntary disclosure model using company-specific characteristics as control variables, which is similar to prior studies of Haniffa and Cooke (2000) and Haniffa and Cooke (2005) as the determinants to the voluntary risk disclosures of ShCCs in Malaysia.

\section{Variables}

The following model was used primarily to test the hypotheses discussed and the variables are defined in Table 3.1:

$\mathrm{VRD}=\beta \mathrm{o}+\beta 1 \mathrm{MD}+\beta 2 \mathrm{DO}+\beta 3 \mathrm{GO}+\beta 4 \mathrm{SIZE}+\varepsilon$ it

\begin{tabular}{|c|c|c|c|}
\hline Types of Variables & Variables & Acronym & Measurement Scale \\
\hline Dependent variable & $\begin{array}{l}\text { Voluntary } \\
\text { Disclosure }\end{array}$ & VRD & Voluntary Risk Disclosure Index \\
\hline $\begin{array}{l}\text { Independent } \\
\text { variable }\end{array}$ & Muslim Directors & MD & $\begin{array}{l}\text { Percentage of Muslim directors on } \\
\text { board } \\
\text { (Muslim Directors / Total Directors) } \mathrm{x} \\
100\end{array}$ \\
\hline $\begin{array}{l}\text { Independent } \\
\text { variable }\end{array}$ & Directors Ownership & $\mathrm{DO}$ & $\begin{array}{l}\begin{array}{l}\text { Percentage of total directors' } \\
\text { ownerships } \\
\text { (Directors Shares / }\end{array} \text { Total Shares) x } 100 \\
\end{array}$ \\
\hline $\begin{array}{l}\text { Independent } \\
\text { variable }\end{array}$ & Government Ownership & $\mathrm{GO}$ & Percentage of government ownership \\
\hline Control Variable & Firm Size & SIZE & Log (Total Assets) \\
\hline
\end{tabular}

Table 3.2: List of variables

[Type here] 


\section{FINDINGS AND DISCUSSION}

\section{Descriptive Statistics}

\begin{tabular}{|l|c|r|r|r|r|r|}
\hline & N & Minimum & Maximum & Mean & Median & $\begin{array}{c}\text { Std. } \\
\text { Deviation }\end{array}$ \\
\hline VRD & 232 & 20.83 & 62.5 & 35.722 & 33.3333 & 7.11068 \\
MD & 232 & 0 & 100 & 38.1724 & 30.0000 & 27.9205 \\
DO & 232 & 0 & 57.1 & 10.5664 & 1.9000 & 16.04113 \\
GO & 232 & 0 & 87 & 9.7819 & 5.3500 & 15.87198 \\
SIZE & 232 & 2.18 & 7.25 & 3.3221 & 3.2102 & 0.67968 \\
\hline
\end{tabular}

Table 4.1 - Descriptive Statistics of all variables

The findings section begins with a discussion on the descriptive statistics for dependent, independent and control variables. Table 4.1 presents the descriptive statistics of the sampled companies. On average, the level of voluntary risk disclosure (VRD Score) is $35.72 \%$, which implies that companies disclosed less than fifty per cent of the voluntary risk information to the users of the annual reports. This percentage is relatively low considering the importance of extra risk information for the users' decision-making. The highest percentage of disclosure for this category is $62.50 \%$ and the lowest is $20.83 \%$. The range of Muslim directors (MD) are from $100 \%$ to $0 \%$. The average of Muslim directors is $30 \%$ which indicates that not all ShCCs are governed by Muslims. The statistics on director ownership (DO) indicate that on average, only $1.9 \%$ is owned by their board. On the other hand, these companies are $5.35 \%$ owned by the government (GO). The firm size (SIZE), proxies by logged total assets, indicates that the sample firms were widely distributed from 7.25 to 2.18 .

\section{VOLUNTARY RISK DISCLOSURE}

The table below outlines the companies that highly disclosed voluntary risk disclosure. Since the mean of voluntary risk disclosure is only $35.72 \%$ as referred in Table 4.1 , these companies actually presented far more than the average compared to the other companies. However, these results are considered low by Ismail \& Rahman (2011), considering the importance of risk management for users to make decisions. The highest percentage of VRD is $56.25 \%$ by Maxis Berhad whereas the lowest is $22.92 \%$ by White Horse Berhad.

\begin{tabular}{lc}
\hline Company & Mean Score Of VRD \\
\hline Maxis Berhad & 56.25 \\
Tenaga Nasional Bhd & 54.17 \\
YTL Corporation Berhad & 54.17 \\
Axiata Group Berhad & 47.92 \\
Petronas Gas Berhad & 47.92 \\
Digi.Com Berhad & 47.92 \\
UMW Holdings Berhad & 47.92
\end{tabular}

[Type here] 


\begin{tabular}{lr} 
Gamuda Berhad & 47.92 \\
Dialog Group Berhad & 47.92 \\
Sime Darby Berhad & 45.83 \\
Telekom Malaysia Berhad & 45.83 \\
Petronas Dagangan Bhd & 43.75 \\
\hline
\end{tabular}

Table 4.2: List of Companies with the highest voluntary risk disclosed on average for 2012-2013

\begin{tabular}{|c|c|c|c|}
\hline Variables & Beta & $\mathrm{t}$ & Sig. \\
\hline $\mathrm{MD}$ & 0.059 & 0.919 & 0.359 \\
\hline DO & 0.045 & 0.746 & 0.456 \\
\hline GO & 0.119 & 1.877 & 0.062 \\
\hline SIZE & 0.469 & 8.058 & 0.000 \\
\hline $\mathrm{R}$ & .489 & & \\
\hline R Squared & 0.239 & & \\
\hline Adjusted R Squared & 0.226 & & \\
\hline F-Statistic & 17.87 & & \\
\hline Significance & 0.000 & & \\
\hline
\end{tabular}

Table 4.3: Regression analysis on Voluntary Risk Disclosure

The above table tabulates the summary of multiple regression results conducted. Based on the regression analysis, the adjusted $\mathrm{R}$ squared value for voluntary risk disclosure is $22.6 \%$. This value indicates that $22.6 \%$ of variation in the dependent variable is caused by variation in independent variables. This regression model is also significant at $F(4,227)=17.87, p<0.01$. Based on the regression results, Muslim directors do not give any significant contributions toward voluntary risk disclosure at 0.350 , where it is higher than 0.05 of significant value. In contrast with Haniffa and Cooke (2005), the existence of Muslim directors is not crucial towards practicing voluntary risk disclosure. According to Haniffa and Cooke (2005), a policy of positive discrimination exists in business opportunities as ethnicity affects corporate behaviour, including its disclosure practice. The mean of Muslims' existence in ShCCs is only 38.2\%, which is respectively low considering that these companies are guided by the Shariah Advisory Council. The low mean score of MD indicates that most ShCCs are owned by non-Muslims. In the study of Haniffa and Cooke (2005), companies dominated by Malay directors will disclose more. This could explain the results of this study where most ShCCs dominated by non-Muslims or non-Malays did not provide additional disclosure of their risks. The first hypothesis is not supported because the P-value is 0.359 . There is no significant relationship between voluntary risk disclosures and the existence of Muslim directors in Shariah Compliant Companies according to the regression result. According to the legitimacy theory, the community expects organisations to be responsive to the environment in which they operate (Tilling, 2004). In the current environment and economy where everything is uncertain, the public expects ShCCs to provide more information as they are known to be guided by the Shariah. ShCCs are widely accepted as companies that operate within the Islamic boundaries, thus, they are expected to be more transparent than normal type companies. In contrast, non-Muslim directors may act like Muslim directors in meeting the expectations of the stakeholders to provide supplementary information in their annual reports. Therefore, no 
difference is seen between Muslim and non-Muslim directors' domination in terms of providing the risk management report.

In addition, director's ownership does not provide any significant contribution towards the voluntary risk disclosure at 0.456 , where it is higher than 0.05 of significant value. This result is similar to prior studies (Ahmed Haji \& Mohd Ghazali, 2013b; Eng \& Mak, 2003). Jensen and Meckling (1976) stated that monitoring directors who have ownership interest might not disclose more to create pressure on the management. According to prior studies, these directors may not disclose more information because they already know the inside information and might be interested to maximise their interest, hence conceal some of the material information (Ahmed, 2013; Chau \& Gray, 2002; Eng \& Mak, 2003; Leung \& Horwitz, 2004). This result also supports Akhtaruddin et. al (2009), where it is actually outsider's ownership that significantly affects company's disclosure. Outside ownership exists to serve as monitors on managers' actions and reduces the likelihood of managers withholding information for their self-interest. Information disclosure is likely to be greater in firms where ownership is dispersed widely (Akhtaruddin, Hossain, \& Yao, 2009). Thus, this study also rejects the hypothesis, as there is no relationship between voluntary risk disclosures and the existence of director's ownership in Shariah Compliant Companies.

Conversely, government ownership shows a significant contribution towards voluntary risk disclosure at 0.062 where it is lower than 0.10 of significant value. This result contradicts with the results of previous studies regarding the impact of government ownership in voluntary disclosure (Ahmed Haji \& Mohd Ghazali, 2013b; Boesso \& Kumar, 2007). Similarly, this study is also in contrast with the result of Haniffa and Cooke (2005), whereby Malay dominated firms owned by the government implemented a responsive legitimation strategy to change perceptions and divert the attention of its various stakeholders from the close relationship enjoyed with the government by increasing social responsibility disclosures. Conversely, most ShCCs are dominated by nonMuslims that are non-Bumiputera. However, they maintain their affiliations with the government using disclosures. In this case, regardless of variation in the board's religions, organisations seek to establish congruence between the social values associated with or implied by their activities and the norms of acceptable behaviour in the larger social system in which they are a part of (Tilling, 2004). This argument is also supported by Ahmed and Mohd Ghazali (2013), where companies that have governmental bodies owning significant portions of their shares provide more information in their annual reports since the government is accountable to the public at large. Thus, this study supports the hypothesis that there is a significant relationship between voluntary risk disclosures and the existence of government ownership in Shariah Compliant Companies.

According to the regression results, firm size has a significant contribution towards the voluntary risk disclosure at 0.000 , where it is lower than 0.05 of significant value. This result is consistent with most previous literatures on voluntary disclosures, where it is indeed affected by the firm size (Ahmed Haji \& Mohd Ghazali, 2013; Al-Janadi et al., 2013; Amran et al., 2009; Ismail \& Rahman, 2013). As companies get bigger, the number of stakeholders also increases. With this increase, the burden of disclosure becomes heavier for the company since it has to cater to the needs of a bigger group of people. Larger companies are under greater public scrutiny and are more likely to face political costs. Consequently, they have the encouragement to give greater devotion to legitimisation management through higher disclosure (Liu \& Taylor, 2008). 


\section{CONCLUSION}

Islamic teachings have started to be accepted globally. This may be the reason for non-Muslim directors to act accordingly and adhere to the Islamic values in managing companies. Moreover, there are also managerial implications of the results. Managers who engage in good practices of information disclosure are recommended to continue doing so. It could also be a wakeup call to other companies that do not provide voluntary disclosure. Accordingly, the existence of government policy has encouraged them to voluntarily disclose their information. Several contributions of this research are identified. This study adds to the literature regarding voluntary risk disclosure in Malaysia, specifically in Shariah compliant companies. Voluntary risk disclosure is expected to enhance ShCCs' transparency towards a more comprehensive risk reporting. This study has found that companies with a high percentage of government ownership also provide more information on risk disclosure in their annual reports. It confirms prior studies that voluntary risk disclosure is also used as a reactive legitimation strategy aimed at diverting attention from questionable business practices, cronyism, nepotism and close affiliations with the government as well as a proactive legitimation strategy to ensure a continued influential voice on both governmental and institutional levels. This result contributes useful information to the regulatory bodies where they are expected to guide their firms toward the best practices of disclosures.

The findings of this research are subjected to several limitations. Firstly, this study only focused on disclosures in corporate annual reports although it is known that managements utilise other mass communication mechanisms too. Hence, future research may consider disclosures in other forms of media such as newspapers, the Internet, and in-house magazines. Secondly, this study only observed Shariah Compliant Companies in Malaysia. Future researchers might want to find the influence of these variables on voluntary risk reporting in other countries as well. Additionally, given the exceedingly complex nature of the business environment as well as time and geographical constraints, there are inherent limits in the ability of positive empirical research to capture all dimensions that influence voluntary risk disclosure policies and practices. Hence, further studies regarding this matter need to be more detailed in order to understand the issues better.

\section{REFERENCES:}

Ahmed Haji, A., \& Mohd Ghazali, N. A. (2013a). The quality and determinants of voluntary disclosures in annual reports of Shari'ah compliant companies in Malaysia. Humanomics, 29(1), 24-42. http://doi.org/10.1108/08288661311299303

Ahmed Haji, A., \& Mohd Ghazali, N. A. (2013b). The quality and determinants of voluntary disclosures in annual reports of Shariah compliant companies in Malaysia. Humanomics, 29(1), 24-42. http://doi.org/10.1108/08288661311299303

Ahmed, S. (2013). Impact of Corporate Governance on Disclosure Quality : Empirical Evidence from Listed Banks in Malaysia, International Journal of Economics and Finance, 7(2), 242279.

Akhtaruddin, M., \& Haron, H. (2010). Board ownership, audit committees' effectiveness, and corporate voluntary disclosures. Asian Review of Accounting, 18(3), 245-259. 
Akhtaruddin, M., Hossain, M. A., Hossain, M., \& Yao, L. (2009). Corporate Governance and Voluntary Disclosure in Corporate Annual Reports of Malaysian Listed Firms. Journal of Applied Management Accounting Research, 7(1), 1-20.

Al-Janadi, Y., Rahman, R. A., \& Omar, N. H. (2013). Corporate Governance Mechanisms and Voluntary Disclosure in Saudi Arabia. Research Journal of Finance and Accounting, 4(4), 25-36.

Amran, A., Bin, A. M. R., \& Hassan, C. H. M. (2009). Risk reporting: An exploratory study on risk management disclosure in Malaysian annual reports. Managerial Auditing Journal, 24(1), 39-57. http://doi.org/10.1108/02686900910919893

Atan, R., S. Maruhun, E. N., Kadir W. A., W. H., \& Jusoff, K. (2010). Annual risk reporting of listed companies in Malaysia, Journal of Modern Accounting and Auditing, 6(8), 26-38.

Beretta, \& Bozzolan. (2004). A Framework for the Analysis of Firm Risk Communication. The International Journal of Accounting, 39(3), 265-288.

Boesso, G., \& Kumar, K. (2007). Drivers of corporate voluntary disclosure: A framework and empirical evidence from Italy and the United States. Accounting, Auditing \& Accountability Journal, 20(2), 269-296. http://doi.org/10.1108/09513570710741028

Bursa Malaysia. (2012b). THE ISLAMIC CAPITAL MARKET. Heterocycles, 85(7). http://doi.org/10.3987/Contents-12-85-7

Cabedo, J. D., \& Tirado, J. M. (2004). The disclosure of risk in financial statements. Accounting Forum, 28(2), 181-200. http://doi.org/10.1016/j.accfor.2003.10.002

Chau, G. K., \& Gray, S. J. (2002). Ownership structure and corporate voluntary disclosure in Hong Kong and Singapore. The International Journal of Accounting, 37(2), 247-265. http://doi.org/10.1016/S0020-7063(02)00153-X

Chen, J. P., \& Janggi, B. L. (2000). The Association between independent non-executive directors, family control and financial disclosures. Journal of Accounting and Public Policy, 19, 285310.

Cheng, E. C. M., \& Courtenay, S. M. (2006). Board composition, regulatory regime and voluntary disclosure. The International Journal of Accounting, 41, 262-290.

Cheung, S. Y., Connelly, J., Limpaphayom, P., \& Zhou, L. (2006). Determinants of corporate disclosure and transparency: Evidence from Hong Kong and Thailand.

Darmadi, S. (2013). Corporate governance disclosure in the annual report: An exploratory study on Indonesian Islamic banks. Humanomics, 29(1), 4-23. http://doi.org/10.1108/08288661311299295

Dobler, M., Lajili, K., \& Ze, D. (2011). Dobler, M., Lajili, K., \& Ze, D. (2011). Attributes of Corporate Risk Disclosure: An International Investigation in the Manufacturing Sector. Journal of International Accounting Research: Fall 2011, Vol. 10, No. 2, pp. 1-22.

Eng, L. L., \& Mak, Y. T. (2003). "Corporate governance and voluntary disclosure”,. Journal of Accounting and Public Policy, Vol. 22, pp. 325-45.

Ferrero-ferrero, I. , Fernández-Izquierdo, M A \& Muñoz-Torres, M J (2012). The impact of the board of directors characteristics on corporate performance and risk-taking before and during the global financial crisis, Review of Managerial Science, Volume 6, Issue 3, pp 207226

Ghazali, N. a. M. (2007). Ownership structure and corporate social responsibility disclosure: some Malaysian evidence. Corporate Governance, 7(3), 251-266. http://doi.org/10.1108/14720700710756535 
Haniffa, \& Cooke, T. E. (2005). The impact of culture and governance on corporate social reporting, 24, 391-430. http://doi.org/10.1016/j.jaccpubpol.2005.06.001

Haniffa, R., \& Cooke, T. (2000). CULTURE, CORPORATE GOVERNANCE AND DISCLOSURE IN MALAYSIAN CORPORATIONS, 2000(November), 28-30.

Healy, P. M., \& Palepu, K. G. (2001). Information asymmetry, corporate disclosure, and the capital markets: A review of the empirical disclosure literature. Journal of Accounting and Economics, 31(1-3), 405-440. http://doi.org/10.1016/S0165-4101(01)00018-0

Ho, S. S. M., \& Wong, K. S. (2001). A study of the relationship between corporate governance structures and the extent of voluntary disclosure. Journal of International Accounting Auditing and Taxation, 10, 139-158.

Ibrahim, H., \& Abdul Samad, F. M. (2011). Corporate Governance and Agency Costs. Advances in Financial Economics, (2006), 109-130.

Ismail, R. F., Arshad, R., \& Othman, S. (2012). THE INFLUENCE OF VOLUNTARY RISK DISCLOSURE ON FIRMS' MARKET VALUE. 3rd INTERNATIONAL CONFERENCE ON BUSINESS AND ECONOMIC RESEARCH (3rd ICBER 2012) PROCEEDING, (March 2012), 2907-2934.

Ismail, R., \& Rahman, R. A. (2011). Institutional Investors and Board of Directors ' Monitoring Role on Risk Management Disclosure Level in Malaysia, 37-62.

Ismail, R., \& Rahman, R. A. (2013). Risk Management Disclosure In Malaysian Islamic Financial Institutions: Pre- And Post-Financial Crisis. Journal of Applied Business Research, 29.2 (Mar/Apr 2013): 419-431.

Jensen, M. C. (1993). The modern industrial revolution, exit, and the failure of internal control systems. The Journal of Finance, 48(3), 831-880.

Jensen, M. C., \& Meckling, W. H. (1976). Theory of the firm: managerial behavior, agency costs and ownership structure. Journal of Financial Economics, 3, 305-60.

Jiang, H., Habib, A., \& Hu, B. (2011). Ownership concentration, voluntary disclosures and information asymmetry in New Zealand. The British Accounting Review, 43(1), 39-53. http://doi.org/10.1016/j.bar.2010.10.005

Jiang, H., Habib, A., \& Smallman, C. (2009). The effect of ownership concentration on CEO compensation-firm performance relationship in New Zealand. Pacific Accounting Review, 21(2), 104-131. http://doi.org/10.1108/01140580911002053

Konishi, N., \& Ali, M. . (2007). Risk reporting of Japanese companies and its association with corporate characteristics. Nternational Journal of Accounting, Auditing and Performance Evaluation I, 4(3), 263-285.

Leung, S., \& Horwitz, B. (2004). Director Ownership and Voluntary Segment Disclosure: Hong Kong Experience. Journal of International Financial Management and Accounting, 15(3), 235-260.

Lindblom, C.K. (1994). The implications of organizational legitimacy for corporate social performance and disclosure, Working Paper for the American Accounting Association Public Interest Section, USA.

Linsley, P. M., \& Shrives, P. J. (2005). Examining risk reporting in UK public companies. The Journal of Risk Finance, 6(4), 292-305. http://doi.org/10.1108/15265940510613633

Linsley, P. M., \& Shrives, P. J. (2006b). Risk reporting: A study of risk disclosures in the annual reports of UK companies. The British Accounting Review, 38(4), 387-404. http://doi.org/10.1016/j.bar.2006.05.002

[Type here] 
Liu, J., \& Taylor, D. (2008). Legitimacy and corporate governance determinants of executives ' remuneration disclosures. Corporate Governance: The International Journal of Business in Society, VoL. 8 NO., pp. 59-72. http://doi.org/10.1108/14720700810853400

Lu, C., Liao, G. M., \& Yang, Y. (2007). Ownership Structure , Information Disclosure and Corporate Value: An Empirical Analysis of Taiwan Companies, 698-704.

Marimuthu, M. (2010). Bumiputera-Controlled Companies: Performance Evaluation Using A Non-Parametric Approach. International Journal of Economics and Finance, 2(2), 178-185. http://doi.org/10.5539/ijef.v2n2p178

MASB. (2009). Financial Reporting from an Islamic Perspective.

Mokhtar, E. S., \& Mellett, H. (2013). Competition, corporate governance, ownership structure and risk reporting. Managerial Auditing Journal, 28(9), 838-865. http://doi.org/http://dx.doi.org/10.1108/MAJ-11-2012-0776

Nazri, M., Mohd, B., Tamkin, J., \& Borhan, B. (2014). The Global Hub Process : Malaysia' s Vision towards Becoming the Islamic Finance Global Hub Country, 5(8), 206-223.

Ousama, a. a., \& Fatima, A. H. (2010b). Voluntary disclosure by Shariah approved companies: an exploratory study. Journal of Financial Reporting and Accounting, 8(1), 35-49. http://doi.org/10.1108/19852511011055943

Rahman, R. A., Kighir, A., Oyefeso, L. O., \& Salam, O. A. (2013). Risk Management Disclosure Practices of Islamic Banks in the Mena Region: An Empirical Analysis, 15(1), 152-160. http://doi.org/10.5829/idosi.mejsr.2013.15.1.2188

Rajab, B. \& Handley-Schachler, M. (2009). Corporate risk disclosure by UK firms: trends and determinants, World Review of Entreprenuership, Management and Sustainable Development, 5(1). http://dx.doi.org/10.1504/WREMSD.2009.026801

Said, R. A., Zainuddin, Y. H., \& Haron, H. (2009). The relationship between corporate social responsibility disclosure and corporate governance characteristics in Malaysian public listed companies. Social Responsibility Journal, 5(2), 212-26.

Securities Commission. (2012). Malaysian Code on Corporate Governance 2012.

Subramaniam, N., \& Mcmanus, L. (2009). Corporate governance , firm characteristics and risk management committee formation in Australian companies, 316-339. http://doi.org/10.1108/02686900910948170

Suchman, M. C. (1995). Managing legitimacy: strategic and institutional approaches. Academy of Management Review, 20(3), 571-610.

Tilling, M. V. (2004). Refinements to Legitimacy Theory in Social and Environmental Accounting. COMMERCE RESEARCH PAPER SERIES NO. 04-6, (ISSN: 1441-3906).

Yatim, P., Kent, P., \& Clarkson, P. (2006). Governance Structures , Ethnicity, and Audit Fees of Malaysian Listed Firms.

Yazid, A. S., \& Muda, M. S. (2006). The Role of Foreign Exchange Risk Management in Malaysia. The Irish Journal of Management, 26(2), 45 - 63. 